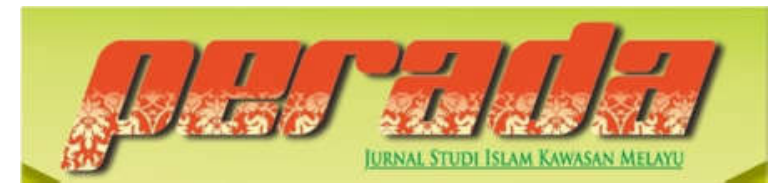

\author{
Perada: Jurnal Studi Islam Kawasan Melayu \\ ISSN 2656-7202 (P) ISSN 2655-6626 (0) \\ Volume 4 Nomor 2, Juli-Desember 2021 \\ DOI: https://doi.org/10.35961/perada.v4i2.395
}

\title{
TINJAUAN HUKUM ISLAM TERHADAP PELAKSANAAN FOTO PREWEDDING
}

\author{
Alex Saputra \\ STAIN Sultan Abdurrahman Kepulauan Riau \\ alexsaputrapg@gmail.com
}

\begin{abstract}
ABSTRAK
Naskah tulisan ini bertujuan untuk mengetahui apa saja faktor yang membuat calon pengantin berkeinginan untuk melaksanakan pemotretatan foto prewedding pada Mandhan Photography (Fotografer Prewedding), dan bagaimana Syariat Islam memandang kegiatan pemotretan prewedding yang dilaksanakan sebelum akad nikah, pada kasus pemotretan yang dilakukan Mandhan Photography. Kupasan artikel ini menggunakan metode deskriptif analisi dengan pendekatan normatif. Sumber data primer berasal dari wawancara penulis dengan saudara Mandhan Photography selaku fotografer prewedding. Hasil penelitian ini menyimpulkan bahwa proses pengambilan foto prewedding benar dilakukan oleh Mandhan Photography dan para calon pelanggan datang kepada Mandhan Photography untuk proses negosiasi kontrak sewa jasa fotografi. Dalam hal ini trend merupakan faktor utama yang menjadi alasan mengapa banyak calon suami dan isteri ingin melakukan sesi foto prewedding. Dan syariat Islam memandang bahwa kegiatan foto prewedding itu haram apabila berlebihan seperti berikhtilah, khalwat dan kasyaful aurat. Namun ulama juga berpendapat bahwa foto prewedding boleh saja asalkan tidak berlebihan seperti halnya dilarang dalam Al-Qur'an dan Hadis.
\end{abstract}

This paper aims to find out what are the factors that make prospective brides want to take prewedding photo shoots at Mandhan Photography (Prewedding Photographers), and how Islamic Shari'a views prewedding photo shoots that are carried out before the marriage contract, in the case of shooting by Mandhan Photography. This article describes a descriptive analysis method with a normative approach. The primary data source comes from the author's interview with Mandhan Photography as a pre-wedding photographer. The results of this study conclude that the process of taking prewedding photos is properly carried out by Mandhan Photography and prospective customers come to Mandhan Photography for the process of negotiating a photography service rental contract. In this case, the trend is the main factor that is the reason why many prospective husbands and wives want to do a pre-wedding photo session. And Islamic law views that pre-wedding photo activities are haram if they are excessive, such as berikhtilah, seclusion and kasyaful aurat. However, scholars also argue that pre-wedding photos are okay as long as they are not excessive as is prohibited in the Qur'an and Hadith.

Kata Kunci : Hukum Islam, Foto Prewedding. 


\section{PENDAHULUAN}

Pada masa kini perkembangan teknologi semakin canggih hingga menciptakan produk teknologi yang bisa digunakan untuk menunjang kebutuhan hidup sehari-hari, hingga pada akhirnya membawa kita kepada perubahan besar, baik itu dari segi positif maupun negatif di kalangan orang banyak. ${ }^{1}$

Kondisi seperti ini tentu sangat mempengaruhi kepada ahlak dan norma manusia masa kini, terlebih majunya perkembang teknologi seolah memperbudak manusia untuk malas berfikir, sehingga membuat kita tidak terbiasa dengan mengkritisi hal-hal yang sekira di anggap sebagai penyimpangan nilai moral dan etika itu sendiri, bahkan nilai sakral agama sekalipun. ${ }^{2}$

Nilai sakral dalam agama ini dapat diambil contoh yaitu perkawinan. Perkawinan dikatakan salah satu hal yang disunnahkan oleh Allah yang diberlakukan untuk seluruh makhluk hidup yang ada di dunia. Semua yang diciptakan oleh Allah adalah berpasangan-pasangan dan berjodoh-jodohan, sebagaimana berlaku juga pada makhluk yang paling sempurna, itulah manusia. ${ }^{3}$

Seperti yang kita ketahui bahwa perkawinan itu dikatakan sah apabila memenuhi rukun dan syaratnya. Tetapi, selain rukun dan syaratnya yang harus dipenuhi, ada pula beberapa sunnah perkawinan yang nampaknya dijadikan sebagai sebuah kebiasaan di lingkungan masyarakat pada masa kini. Salah satu contohnya adalah "resepsi", atau dalam bahasa Arab disebut dengan walimatul 'urs.

Untuk sebagian ulama yang ber mazhab Syafi'i, Hambali, dan Maliki,

1 Muhammad Djakfar, Agama Etika, dan Ekonomi (Malang: UIN Press, 2007), hal. 3.

2 Muhammad Djakfar, Agama Etika, dan Ekonomi, hal. 4.

${ }^{3}$ Beni Ahmad Saebani, Perkawinan Dalam Hukum Islam Dan Undang-Undang (Bandung: CV. Pustaka Setia, 2007), hal. 13. berpendapat jika menghadiri acara walimatul urs bagi orang yang diundang adalah wajib. Mengahadiri undangan sebuah pesta perkawinan hukumnya sama seperti menghadiri pesta-pesta yang lainnya, seperti halnya termaktub dalam kitab $A l$-Bahr. Ini mengambil hukum Qiyas dimana jumhur ulama tidak berbeda pendapat tentang menghadiri acara tasyakuran seperti aqiqah, dan lainnya ialah sunnah, maka dari itu walimatul 'urs perkawinan di qiyaskan kepada pesta-pesta lainnya. ${ }^{4}$ Bercerita tentang walimatul urs, maka tidak lepas dari hal-hal yang menghiasi setiap sudut ruangan walimatul urs. Hiasan-hiasan itu tepatnya adalah pajangan foto prewedding kedua calon pengantin. Dalam foto prewedding tersebut menceritakan sepasangan kekasih keturunan Adam dan Hawa sedang berbahagia. Sebuah gambaran sekali dalam seumur hidup yang terlukiskan dalam album foto prewedding. Seolah-olah gambaran manis masa-masa pacaran terangkum dalam satu album foto prewedding.

Pada masa Nabi memang benar tidak ada pengambilan foto prewedding ini, dan hal tersebut bukanlah bagian dari rentetan sunnah penikahan seperti halnya walimatul 'urs. Dan juga tidak ada masalah jika pengambilan foto ini dilakukan, karena tidak sampai kepada rukun dan syarat pernikahan. Namun perlu digaris bawahi, proses pengambilan foto prewedding selalu memunculkan adegan-adegan mesra bagi kedua calon pengantin, padahal jelas-jelas mereka belum sah sebagaai pasangan suami dan isteri.

Foto prewedding dengan bermesraan menuai banyak pertanyaan bagi para pemikir Islam dan ulama. Permasalahan ini dikarenakan saat melakukan foto, pasangan mempelai belum melakukan akad nikah, atau belum muhrim. Ditambah

4 Mohammad Asnawi, Nikah dalam Perbincangan dan Perbedaan, (Jogja: Darussalam, 2004), hal. 181. 
lagi, banyak ditemui calon pengantin berpose dengan mesra. Padahal secara agama belum terjadi adanya akad nikah. Oleh sebab itu, hal-hal besar yang dianggap sepele seperti ini menjadi kebiasaan di masyarakat, selain ada bentuk adegan mesra, biasanya calon pengantin wanita mengenakan pakaian ketat menunjukkan lekuk tubuh. Walau ada juga foto prewedding yang mengedepankan kaidah-kaidah Syariat Islam dengan cara mengenakan pakaian yang longgar dan menutupi aurat serta menjaga jarak dari sentuhan, tetapi foto prewedding yang mengenakan pakaian ketat dan beradegan mesralah yang lebih dominasi dan membudaya di tengah fakta yang ada, hingga na'urubillabi min dralik tidak jarang ditemukan adegan yang selayaknya bagi mereka yang belum menikah, adegan dengan penuh unsur syahwat seperti merangkul, memeluk, menggendong, bahkan bercumbu mesra. Inilah beberapa bentuk kebebasan yang berlebihan para calon pengantin yang tidak lagi memperhatikan norma-norma agama, padahal tanpa adanya kontak sentuh dan memamerkan aurat, foto prewedding tetap menggambarkan bahwa mereka itu kedua mempelai yang akan menjadi raja dan ratu sehari dalam walimatul 'urs.

Mengenai hukum foto prewedding, pernah mendapat perhatian dari Majelis Ulama Indonesia (MUI) se-Kalimantan. MUI menjelaskan mengenai foto prewedding dalam Fatwa Nomor 5/Fatwa/MUIKalimantan/XII/2014, tentang "Hukum Pembuatan Foto Prewedding dan Mencetaknya dalam Undangan”. Adapun hasil keputusan tersebut adalah:

1. Pembuatan foto prewedding dan mencetaknya pada undangan sebelum akad nikah, telah melanggar beberapa hukum syara', seperti khalwat, ikbilat, membuka aurat, bersentuhan dengan lawan jenis yang haram dan tabarruj. Hukumnya haram.
2. Foto prewedding yang menampilkan kemesraan yang mengumbar syahwat walaupun dilakukan setelah menikah kemudian dicetak kepada undangan atau dipajang agar dilihat banyak orang. Hukumnya haram. ${ }^{5}$

Dalam Islam selama belum terjadinya akad yang sah di antara laki-laki dan perempuan maka status keduanya masih sebagai orang yang bukan muhrim. Walaupun pada dasarnya pasangan yang melakukan sesi foto prewedding akan melangsungkan pernikahan, tetapi masih tetap harus menjaga batasan-batasan yang telah ditentukan oleh agama Islam. Hal ini seperti, yang dicontohkan Nabi dalam konsep ta'aruf sebagai proses memantapkan dan saling mengenal antara calon pasangan pengantin. ${ }^{6}$

Foto prewedding merupakan suatu pengambilan gambar yang dilakukan oleh pasangan yang belum sah menjadi suami istri atau sebelum pernikahan. Foto prewedding kini seperti menjadi hal yang diwajibkan bagi sepasang calon pengantin. Foto prewedding sendiri mempunyai nilai fungsi yang berbeda-beda, ada yang menggunakannya sebagai dokumentasi, ada yang menggunakannya sebagai aksesoris dalam pesta pernikahannya, ada juga yang menggunakannya untuk desain undangan maupun untuk souvenir pesta pernikahan.

Konsep dan proses dalam pengambilan gambar menjadi pertimbangan dari fotografer ataupun permintaan dari pelanggan. Konsep yang dimaksud disini adalah dari gaya berfoto, lokasi pengambilan foto, dan pakaian yang digunakan untuk foto prewedding. Konsep tersebut biasanya sudah dibicarakan atau

${ }^{5}$ Keputusan MUI se-Kalimantan Nomor 05/Fatwa/MUI-Kalimantan/XII/2014, tentang Hukum Pembuatan Foto Prewedding dan Mencetaknya dalam Undangan.

6 Rosita, Kusnulia dan Yeniar Indriana. "Pengalaman Subjektif Istri yang Menikah dengan Proses Taaruf”, (Jakarta:Empati, 2014) hal. 311-323. 
dirancang bersama sebelum pelaksanaan pengambilan foto antara pelanggan dengan fotografernya. Biasanya pelanggan hanya memilih tempat atau lokasi yang akan digunakan untuk pengambilan foto dan gaun atau pakaian yang dipakai untuk foto prewedding.

Kemudian juga sebagai pelaku dari fotografer itu sendiri juga tidaklah mudah, namun bagi Mandhan Photography ia tetap profesional dalam melakukan pekerjaannya, dan terbukti banyak sekali para calon pengantin khususnya yang muda-mudi millenial berminat untuk melakukan foto prewedding kepadanya. ${ }^{8}$ Dan dilihat dari hasil-hasil foto prewedding ini terbukti nampak kemesraan-kemesraan yang tidak lazim pada calon pengantin yang jelas belum sah menikah. Terlepas dari ketidaktahuan fotografer itu sendiri atau itu merupakan bentuk dari profesionalitas permintaan client dalam berkerja.

Kembali kepada halnya pernikahan, sebuah pernikahan yang suci sungguh telah dikotori dengan kebiasaan melakukan pemotretan prewedding yang beradegan dan berpakaian terlarang oleh Syariat Islam. $\mathrm{Hal}$ ini cukup membuktikan bahwa berkembangnya teknologi tidak menentukan prilaku di lingkungan masyarakat justru membaik, malah dijadikan sebagai fasilitas untuk melanggar norma-norma syariat yang telah termatub dalam al-quran dan al-hadits. Bahkan hal ini menjadi kebiasaan demi kebutuhan konten kekinian di media sosial untuk mendapatkan pujian-pujian.

Adapun fakta di lapangan yang terjadi dari 18 pelanggan foto prewedding yang melakukan sesi foto kepadanya rata-

\footnotetext{
7 Adindha Putri Arifianing Kasih," Pandangan Masyarakat Terbadap Foto Prewedding Dalam Undangan Pernikahan Perspektif Hukum Islam”, SKRIPSI IAIN Purwokerto 2019, hal. 23.

8 Hasil wawancara dengan Mandhan Photography (fotografer prewedding), pada tanggal 13 Agustus 2021 di Desa Pengudang, Kecamatan Teluk Sebong, Kabupaten Bintan.
}

rata meminta pose foto yang mengarah kepada hal-hal tidak seharusnya yang dilakukan oleh pasangan calon pengantin belum sah ikatannya dalam Agama. Oleh sebab itu sebagai pelaku dari fotografer prewedding ia tetap malakukan tugas itu secara profesional dalam artian memaksimalkan hasil foto seperti yang diharapkan oleh pelanggan. ${ }^{9}$

Kemudian dari pada itu penulis juga dapat menyimpulkan bahwasannya realita yang ada dalam pelaksanaan foto prewedding sering kali berbenturan dengan Syariat Islam dan otomatis ini mengandung masalah. Berdasarkan masalah dan latar belakang di atas maka penelitian ini merupakan penelitian hukum Islam dengan pendekatan normatif.

\section{FOTO DAN FOTOGRAFI DALAM ISLAM}

Foto adalah gambar diam baik berwarna maupun hitam-putih yang dihasilkan oleh kamera yang merekam suatu objek atau kejadian atau keadaan pada suatu waktu tertentu. Kegiatan yang berhubungan dengan foto diistilahkan dengan fotografi. Secara etimologi sebutan ini bermula dari kata Yunani, "Photos" yang berarti cahaya dan "graphien" yang berarti menulis atau menggambar. ${ }^{10}$

Salah satu kegunaan fotografi adalah untuk mendokumentasi aktivitas manusia. Karena karya foto merupakan dokumentasi yang dapat disimpan dalam kurun waktu tertentu. Hampir semua aktivitas manusia dengan berbagai kehidupannya, bisa difoto untuk dijadikan dokumentasi.

Prewedding berasal dari kata bahasa Inggris yang dalam bahasa Indonesia "foto prewedding" artinya adalah foto yang dilakukan sebelum pernikahan. Artinya

\footnotetext{
9 Hasil Wawancara bersama Mandhan Photogrpahy, fotografer prewedding Desa Pengudang, 15 Juni 2021.

${ }^{10}$ Ensiklopedi Nasional Indonesia, Jakarta: PT. Delta Pamungkas, 1997, Cet. Ke-3, hal. 371.
} 
semua prosesi yang dilakukan sebelum acara pernikahan dan diabadikan dalam sebuah foto, maka semua foto tersebut adalah foto prewedding. Dengan kata lain foto-foto prewedding dapat berupa foto pertunangan, foto acara midodareni (sebuah adat jawa yang dilaksanakan pada malam sebelum pernikahan), foto undangan pernikahan, dan lain sebagainya. ${ }^{11}$

Konsep pada foto prewedding mencakup beberapa hal, contohnya lokasi pengambilan gambar, pakaian dan gaya pose yang akan diambil gambarnya. Konsep dan proses dalam pengambilan gambar itu sendiri menjadi pertimbangan, entah dari fotografer itu sendiri maupun permintaan dari pelanggan. Perihal awal yang biasa dicoba oleh calon pengantin yang hendak melakukan gambar prewedding merupakan mencari inspirasi, baik itu pose difoto, baju, tempat hingga fotografer yang diidamkan. Dalam memilih fotografer, klien berikan keinginan seperti apa konsep fotonya kepada fotografer tentang tema yang diidamkan. Sehabis tema didiskusikan fotografer memiliki pemikiran posisi buat mewujudkan tema yang di idamkan. Sehabis tema serta posisi disepakati bersama, setelah itu baju serta perias pula butuh dipertimbangkan dengan kacamata fotografer.

Sejak munculnya fotografi dalam kehidupan manusia, para ulama terdahulu telah menjelaskan tentang kedudukan hukumnya. Diantara ulama yang paling mashur adalah pendapat mufti kerajaan Mesir, Syaikh Muhammad Bakhit AlMuthi'I, yang ditulis dalam bukunya " $A l$ Qaul Al-Kafi fi Ibahah At-Tashwir AlFutughrafi". Menurut pendapatnya bahwa fotografi hukumnya halal dan mubah. Dia berpendapat berdasarkan illat yang disebutkan dalam hadits-hadits yang

https://www.kemejingnet.com/2016/03/arti-danpengertian-foto-pre-wedding.html (Dilihat pada tanggal 10 maret 2021, jam: 21:30 WIB). mengharamkan dan melaknat orang yang mengambar adalah menyamai ciptaan Allah SWT. ${ }^{12}$ Dan hal ini menyangkut dengan gambar yang dibendakan atau bisa disebut dengan patung. ${ }^{13}$

Walaupun fotografi diperbolehkan dalam islam akan tetapi, harus diperhatikan bahwa objek dari gambar tersebut harus sesuai dengan Syariat Islam, atau objek gambar mempunyai pengaruh untuk menetapkan hukum terhadap haram dan halal. Adapun mengenai hukum halalnya seperti seseorang yang mengambil gambar dengan objek sesuai syariat islam. Adapun yang bersifat haram yaitu, mengambil gambar dengan pakaian telanjang dan menampakan aurat wanita yang dapat membangkitkan syahwat seseorang, tidak diragukan lagi bahwa semua itu hukumnya haram baik mengambil gambar, melihat gambar, maupun menyebarluaskan gambar tersebut. ${ }^{14}$

Pendapat mengenai fotografi juga ditegaskan kembali oleh Yusuf Al-Qardawi dalam bukunya yang berjudul "Fatwafatwa Mutakhir". Sebagai berikut: "Pemotretan tidak apa-apa asalkan sasaran yang dipotret itu halal. Diharamkan memotret perempuan telanjang atau setengah telanjang misalnya: memotret sasaran lain yang tidak diperbolebkan syariat. Memotret anak, teman, pemandangan alam, dan pesta yang bersih. Pemotretan dalam semuanya itu tidak apa-apa. Ada situasi-situasi tertentu yang sangat memerlukan, sehingga pemotretan boleh dilakukan, babkan orang-orang yang paling keras berpegang pada agama pun memperbolebkanya, seperti membuat surat-surat

12 Sebagai isyarat kepada hadis Aisyah, "Manusia yang akan disiksa sangat pedih di hari kiamat adalah yang menandingi ciptaan Allah."HR. Al-Bukhari Kitab Al-Libas (5954)., dan Muslim, Kitab Al-Libas wa Az-Zinah (2107).

13 Yusuf Al-Qardhawi, "Fiqh Muqasid Syariab" Terjemahan: Arif Munandar Riswanto, (Jakarta Timur: Pustaka Al-Kautsar, 2007), hal. 74.

14 Yusuf Qardawi, Halal dan Haram, Tjr. Abu Sa ${ }^{\text {ee }}$ id \& Annur Rafiq Shaleh Tamhid, Jakarta: Robbani Press, 2002, hal. 126. 
identitas, kartu tanda penduduk, surat kewarganegaraan, passport dan lain sebagaianya"."

Dari pendapat di atas dapat disimpulkan bahwa, pada dasarnya hukum fotografi adalah diperbolehkan. Asalkan objek dari foto tersebut tidak bertentangan dengan syariat islam. Fotografi juga dapat bersifat haram apabila yang menjadi objek foto bertentangan dengan syariat islam.

\section{PELAKSANAAN FOTO PREWEDDING OLEH MANDHAN PHOTOGRAPHY}

\section{Dalam pelaksaan foto prewedding yang dilakukan oleh Mandhan Photography pertama melakukan proses pemasaran karya foto baik di sosial media guna menarik calon perhatian calon pelanggan yang akan menggunakan jasa fotografi.}

Pada proses pengambilan foto awalnya calon pelanggan datang kepada Mandhan Photography untuk memesan jasa fotografi, supaya kesepakatan pemesanan jasa itu terjadi pelanggan harus membayar uang muka guna terjalinnya kepastian antara kedua belah pihak. Sehingga pihak Mandhan Photography bisa mengalokasikan waktunya untuk menghindari terjadinya bentrok waktu dengan kontrak jasa fotografi dari pelanggan lain yang sudah diatur. Sebelum sesi foto berlangsung pihak pelanggan dan Mandhan Photography membuat kesepakatan dalam bentuk pose, jenis pakaian, dan lokasi yang akan digunakan pada saat sesi foto nantinya. Berdasarkan hasil wawancara bersama pemilik label fotografi Mandhan Photography ia mengatakan biasanya pelanggan yang merekomendasi dari ketiga hal tersebut, ia hanya melakukan pemotretan saja, sisanya

15 Yusuf Al-Qardhawi, Fatwa-Fatwa Mutakhir, tjr: H.M.H, Al-Hamid Al-Husaini, Bandung: yayasan Al-Hamid, 2000, cet: 4, hal. 880881. diserahkan kepada pelanggan supaya hasil akhir dari foto nantinya sesuai dengan keinginan pelanggan.

Berikut kategori pose foto prewedding yang diminati pelanggan ialah:

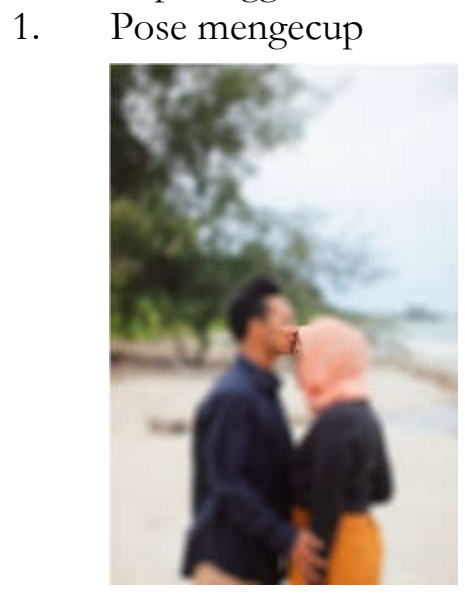

Sumber: Dokumentasi Mandhan Photography

Mengecup adalah mencium dengan melekatkan bibir. ${ }^{16}$ Pada foto ini terlihat sedang melakukan pose foto mengecup kening. Pose ini sangat mencerminkan kasih sayang yang sempurna dan menghargai wanita secara romantis. Pada pose ini, menggambarkan posisi kedua pasangan saling berhadapan supaya memberikan kesan romantis dan terlihat memberikan senyuman saat dicium untuk memperkuat rasa di dalam foto.

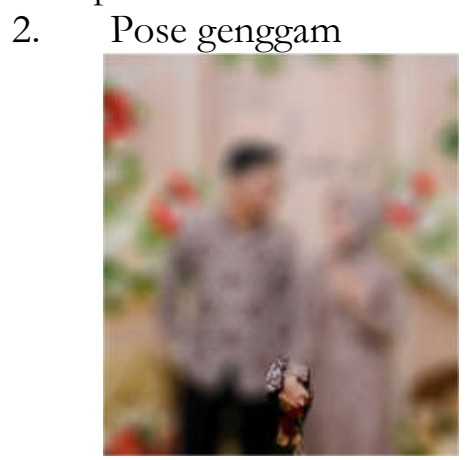

Sumber: Dokumentasi Mandhan Photography Genggam yaitu kepalan atau cengkraman tangan pada waktu keadaan

\footnotetext{
${ }^{16}$ www.kbbi.kemendikbud.go.id/mengecup, diakses pada 3 November 2021, pada jam 20.00 WIB.
} 
memegang. ${ }^{17}$ Pose ini menggambarkan sedang menuntun wanita dan mengkomunikasikan perasaan pria kepada wanita dan ingin menghabiskan waktu lebih lama bersama si wanita.

3. Pose merangkul

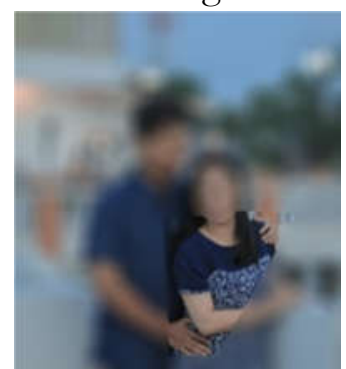

Sumber: Dokumentasi Mandhan Photography

Merangkul merupakan melingkarkan lengan pada pundak tubuh, pinggang, memepetkan badan pada badan orang lain sambil melingkarkan kedua lengan, mendekap. ${ }^{18}$ Pose ini menceritakan bahwa pria sedang menjaga, memberikan rasa nyaman, saling membutuhan rasa nyaman di antara keduanya dan hanya ingin menggoda. Dengan pelukan dari belakang si pria ingin selalu ada untuk wanitanya.

4. Pose berjarak

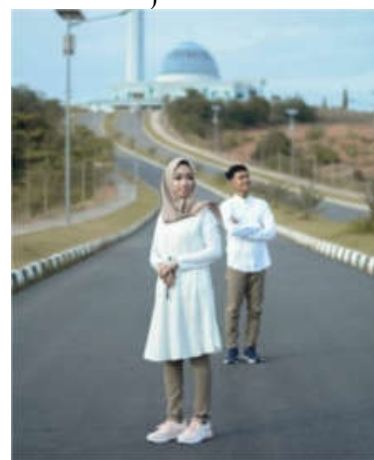

Sumber: Dokumentasi Mandhan Photography

Berjarak merupakan ada antara atau batasan sekurang-kurangnya harus berjarak satu meter. ${ }^{19}$ Pose ini menceritakan bahwa

17 www.kbbi.kemendikbud.go.id/genggam, diakses pada 3 November 2021, pada jam 20.00 WIB.

18

www.kbbi.kemendikbud.go.id/merangkul, diakses pada 3 November 2021, pada jam 20.00 WIB.

19 www.kbbi.kemendikbud.go.id/berjarak, diakses pada 3 November 2021, pada jam 20.00 WIB. setiap berpasangan tidak selalu harus berdekatan dan bermesraan, terlihat keduanya saling berjarakan, hal ini tetap menunjukkan kemistri di dalam foto.

Dari 18 pasangan calon pengantin yang melakukan sesi foto prewedding yang menggunakan jasa fotografinya, rata-rata memilih untuk berpose yang mesra dan menggunakan pakaian yang menampakkan aurat. Dengan alasan untuk koleksi pribadi pihak konsumen tersebut. Namun pihak Mandhan Photography megaskan bahwa ia seorang foto muslim dan sudah mencoba untuk mengarahkan kepada calon pengantin untuk tetap berpose sesuai syariat Islam tetapi hal itu menjadi tuntutan oleh konsumen karena tidak dianggap profesional dalam bekerja. Pada akhirnya karena kerap mendapat kritikan dan tuntutan profesionalitas dalam bekerja ia menuruti kemauan dari konsumen tersebut.

Masalah halal dan haram begitu sentral dalam pandangan kaum muslimin, hal ini karena ia merupakan batas antara yang hak dan yang batil, atau lebih jauh antara surga dan neraka. Halal dan haram akan selalu dihadapi oleh kaum muslimin setiap waktu dalam rentang kehidupannya. Sehingga menandakan bepata pentingnya kita mengetahui secara rinci batas antara apa yang halal dan apa yang haram. Mengetahui persoalan halal dan haram ini kelihatan mudah sepintas, tetapi kemudian menjadi sangat sukar ketika berhadapan dengan kehidupan keseharian, yang kadang menjadi kabur, sulit membedakan mana yang halal dan mana yang haram, atau bahkan menjadi syubhat.

\section{ANALISIS HASIL FOTO PREWEDDING DALAM HUKUM ISLAM}

Berdasarkan temuan dan paparan sebelumnya, maka disajikan anlisa sebagai berikut.

\section{Pose mengecup}


Pada foto prewedding di atas menunjukkan pria dan wanita sedang melakukan adegan mesra layaknya pasangan suami dan istri. Sang pria ada yang memegang, mengecup kening sang wanita, dengan posisi tubuh yang begitu dekat oleh keduanya. Ditambah sang wanita mengenakan hijab namun memakai baju yang menunjukkan lekuk tubuhnya hingga terlihatlah bentuk dari tubuhnya tersebut. Betapa norma-norma Syariat Islam mengenai khalwat, ikhtilat dan kasyaful aurat telah lengkap terkomposisi pada foto prewedding di atas.

Islam tidak pernah membahas terkait foto prewedding, karena pada zaman turunnya Al-Qur'an belum ada sama sekali kegiatan pemotretan seperti sekarang ini. Terlebih juga ulama salaf belum ada yang membahas mengenai masalah hukum foto prewedding. Namun karena adanya pose dalam foto prewedding tersebut yang tampak mengandung unsur khalwat dan ibktilat, maka penulis menarik dalil Q.S Al-Israa (17):32. Allah SWT berfirman:

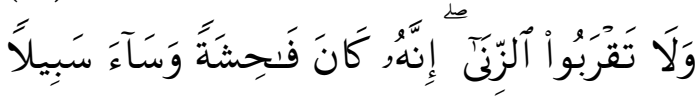

Artinya: "Dan janganlah kamu mendekati zina; Sesungguhnya zina itu adalah suatu perbuatan yang keji. dan suatu jalan yang buruk.",20

Para ulama berkata, "Firman Allah SWT "janganlab kamu mendekati zina" ini lebih mendalam dari pada di katakan (janganlah kalian semua berzina), ${ }^{21}$ karena kalau saja bahasa dalam Al-Qur'an itu menggunakan kata "jangan berzina" maka yang dilarang itu berzinanya saja, tetapi hal-hal yang mendekati perbuatan zina seperti pose pada Foto Prewedding diatas tidak dilarang. Itulah mengapa bahasa yang

${ }^{20}$ Al-Qur'an In Word.

21 Syaikh Imam Al-Qurtubi, Tafsir Al Qurtubi, Penerjemah Ahmad Khotib, (Surah AlHijr, Annaml, Al Israa dan Al-Kahfi), (Pustaka Azzam: Jakarta Selatan, 2008), hal. 627. dipakai dalam Al-Qur'an adalah jangan mendekati zina, karena bahasa itu lebih mendalam dan menjurus kepada perilaku ikbtilat dan khalwat yang sering terjadi di sekitar.

Dalam pose pada foto prewedding diatas cukup menjadi fakta bahwasanya perilaku ikhtilat dan khalwat seperti itulah yang dimaksud para ulama dalam menafsirkan Q.S Al-israa (17): 32 sebagai bentuk perbuatan mendekati zina. Pose pada foto prewedding di atas sang wanita yang berbaring di atas paha pria dan sang pria mencium keningnya, besar kemungkinan adegan tersebut mengundang syahwat di antara kedua belah pihak.

Akhirnya gaya pose antara sang pria dan wanita pada foto prewedding di atas mengandung unsur pornografi dan pornoaksi. Mengenai perilaku ikhtilat dan khalwat yang terjadi pada foto prewedding diatas, Nabi Muhammad telah menyinggungnya dalam Hadits yang berikut, Rasululallah SAW bersabda:

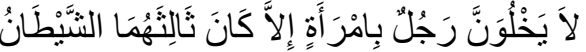

Artinya: "Janganlah salab seorang di antara kalian berduaan dengan seorang wanita (yang bukan mahramnya) karena setan adalah orang ketiganya." (HR. Ahmad 1:18) ${ }^{22}$

Pose pada foto prewedding sebelumnya, tergambarkan contoh sikap ikhtilat dan khalwat yang terlarang oleh Syariat Islam. Dan perilaku seperti itulah awal dimana perzinahan biasanya terjadi, karena syetan telah hadir di antara mereka untuk menggoda supaya manusia terjerumus dalam lubang perzinahan. Hadits di atas merupakan hadits yang langsung diucapkan oleh baginda Nabi Muhammad SAW. Sungguh tidak ada lagi keraguan dari apa-apa yang disampaikan beliau tentang bahayanya perilaku ikbtilat dan khalwat.

22 Imam Ahmad bin Muhammad bin Hanbal, Musnad Imam Ahmad, Jilid 1, Jakarta: Pustaka Azzam, 2009), hal. 303. 
Kemudian pada foto di atas tergambarkan pose sang pria yang mencium wanita. Mengenai hal ini terdapat kisah seorang pemuda pada zaman Nabi telah mengaku sengaja mencium wanita non mahrom. Berdasarkan asbaabunnuzul tersebut, maka turunlah Q.S. Huud (11):14. Allah SWT berfirman:

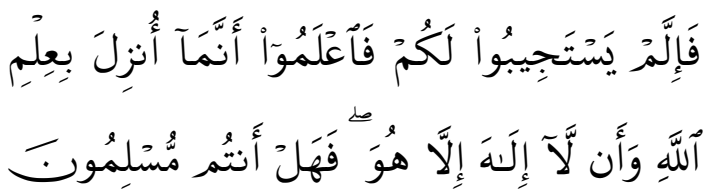

Artinya: "jika mereka yang kamu seru itu tidak menerima seruanmu (ajakanmu) itu Maka ketabuilah, sesunggubnya Al Quran itu diturunkan dengan ilmu Allah, dan bahwasanya tidak ada Tuban selain Dia, Maka maukah kamu berserah diri (kepada Allah)?,23

Dari contoh pose foto di atas, itulah peristiwa mencium wanita yang bukan mahrom tentu juga termasuk perbuatan mendekati zina, karena terlebih perilaku mencium cepat sekali merangsang birahi di antara wanita maupun lelaki. sebagaimana para ulama telah menafsirkan dalam Q.S Al-Israa (17):32. Belum lagi, pakaian yang sejatinya mempunyai fungsi untuk menutupi bagian-bagian aurat, sama sekali tidak teraplikasikan pada pakaian si wanita pada Foto Prewedding tersebut. Hingga akhirnya nampaklah pada foto prewedding tersebut bagian-bagian aurat yang sejatinya wajib ditutupi seperti lekuk tubuh. Mengenai hal ini, Allah SW'T telah menyinggungnya dalam Q.S Al-A'raaf (7):26. Allah SWT berfirman:

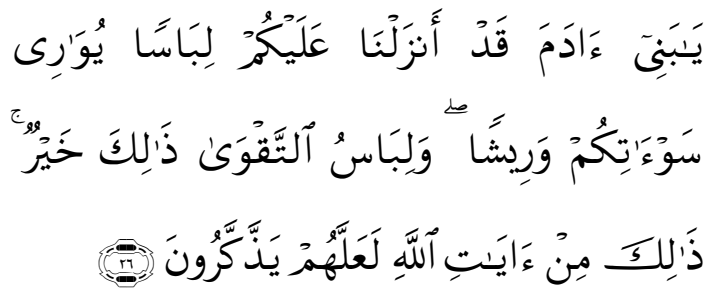

${ }^{23} \mathrm{Al}-\mathrm{Qur}$ 'an In Word.
Artinya: "Hai anak Adam, sesunggubnya kami telah menurunkan kepadamu pakaian untuk menutup auratmu dan pakaian indah untuk perbiasan. dan pakaian takwa itulah yang paling baik, yang demikian itu adalah sebahagian dari tanda-tanda kekuasaan Allah, mudah-mudahan mereka selalu ingat. ${ }^{, 24}$

Tentang ayat ini, Abu Ja'far berkata: "Allah SWT berfirman kepada orang-orang arab bodoh yang melakukan tawaf di Baitullah dengan telanjang, karena mengikuti perintah syaitan dan tidak taat kepada Allah. Dia memberi trabu mereka akan tertipunya mereka dengan tipuan syaitan bingga syaitan dapat menguasiai mereka dan berhasil membuka tutupan Allah yang Ia karuniakan kepada mereka bingga aurat mereka nampak dan sebagian dari mereka dan sebagian melibat aurat lainnya, sesunggubnya Allah telah memberi anugerah apa yang dapat menutupi aurat mereka. Adam dan Hawa yang tertipu oleh tipuan iblis, hingga ia berhasil membuka tutupan Allah yang di karunikan kepada mereka, sebingga nampaklah aurat mereka. Iblis berbasil menelanjangi mereka.",25

Takwil firman Allah: wariisya (dan pakaian yang indah), Abu Ja'far berkata: para ahli qira'at berbeda pendapat dalam membaca lafazh wariisyaaa. Mayoritas ahli qira'at membaca wariisyaa, tanpa huruf alif. Sementara itu, disebutkan Ziir bin Hubaisy dan Hasan Al-bashri, bahwa mereka semua membaca wariyasyaa. ${ }^{26}$ Takwil firman Allah: (Dan pakaian taqwa itulah yang paling baik) Abu Ja'far berkata: Para ahli takwil berbeda pendapat tentang firman Allah ini. Sebagian berpendapat bahwa lafazh walibasuttaqwa maksudnya adalah "keimanan".

${ }^{24} \mathrm{Al}-\mathrm{Qur}$ 'an In Word

25 Abu Ja'far Muhammad bin Jarir AthThabari, Tafsir Ath-Thabari, Penerjemah Abdul Somad, Yusuf Hamdani, Jakarta Selatan: Pustaka Azzam, 2008), hal. 906.

${ }^{26}$ Ibid, hal. 911

${ }^{27}$ Ibid, hal. 915 
Peristiwa orang-orang Arab bodoh yang mengelilingi ka'bah dengan telanjang merupakan bentuk tidak taatnya kepada Allah SWT sehingga hal tersebut membuatnya mengikuti perintah Syaitan. Hal ini tidaklah jauh dari bedanya dengan pakaian wanita pada foto prewedding di atas. Ia memang berpakaian, namun tidak menutupi lengkuk tubuhnya dan memperlihatkan aurat itu kepada yang bukan mahramnya dimana seharusnya itu tertutupi. Libaasuttaqwa yang sejatinya melekat pada diri seorang wanita, kini banyak ditanggalkan, dan malah memilih memamerkan auratnya di muka umum, termasuk di muka kamera saat sesi pengambilan gambar prewedding.

Selanjutnya masih mengenai aurat yang harus ditutupi oleh pakaian, Rasulullah SAW bersabda :

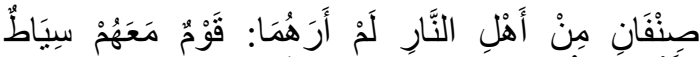

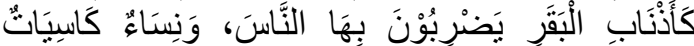

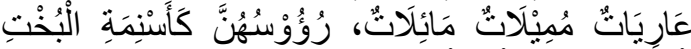

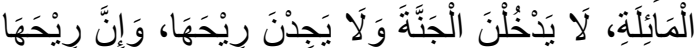

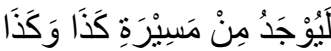

Artinya: "Ada dua golongan penduduk neraka yang belum aku lihat, orang-orang yang membawa cemeti layaknya ekor sapi, mereka memukul orang-orang dengannya, dan kaum perempuan yang berpakaian tapi telanjang, yang lenggok-lenggok dan memiringkan, kepala mereka seperti sekedup unta yang miring, mereka tidak masuk surga tidak mendapatkan baunya, padahal bau surga tercium dari jarake perjalanan sekian dan sekian." (H.R Muslim) ${ }^{28}$

Ahli ilmu menafsirkan, "perempuan yang berpakaian tapi telanjang", sebagai perempuan yang mengenakan pakaian sempit, atau pakaian tipis tidak menutupi bagian tubuh di bawahnya, atau pakaian pendek. Syaikhul Islam menjelaskan bahwa pakaian kaum perempuan di dalam rumah pada masa Nabi Muhammad SAW adalah antara mata kaki dan telapak tangan,

28 Sahih Muslim, Kitab Pakaian dan Perbiasan, Bab: Wanita Berpakaian Tapi Telanjang, Nomor. 3971. Dibagikan Via Aplikasi Android Hadits alBukhari. bagian tubuh antara keduanya tertutup meski mereka berada di dalam rumah. Sedangkan jika mereka keluar menuju pasar, bahwa pakaian kaum perempuan hanya mengenakan pakaian panjang yang menjulur ke tanah, lalu Nabi Muhammad SAW memberi keringanan bahwa mereka boleh menjulurkan (jilbab) hingga ke lengan, tidak lebih dari itu.

\section{Pose mengenggam}

Pada foto prewedding berikutnya nampaklah sepasang calon pengantin saling bergandengan erat berdua. Si wanita yang mengenakan baju belum cukup menutup auratnya. Hal itu karena bahan pakaian yang di kenakannya masih transparan, hingga terlihat lengan dan bahunya, kemudian lekuk tubuh juga ikut terlihat. Belum lagi kain kerudung tidak nampak di kepala sang wanita, membuat rambut dan lehernya bebas terlihat.

Walaupun tidak sampai mencium seperti adegan pada foto prewedding yang pertama, namun adegan memegang lengan dan menempelkan tubuh pada foto prewedding psada pose ini termasuk dalam kategori ikhtilat dan khalwat yang dimaksud Q.S Al-israa (17): 32. Asy-Syaukani berkata: "Dalam pelarangan zina dengan menggunakan muqaddimabnya dan larangan ini paling kuat. Sesunggubnya segala sesuatu sarana menuju ke haram, maka haram pula bukumnya berdasarkan makna eksplisit ungkapan (Walaa taqrabuz:inaa) itu." ${ }^{29}$

Adapun mendekati zina dalam prakteknya ada beberapa pendekatan, seperti khalwat, ikhtilat, mengumbar aurat, pandangan mata yang liar dan pikiran atau hati yang kotor. Hubungan seksual illegal (Zina) membuka jalan bagi banyak kerusakan individual, sosial, dan keluarga. Karenanya, hal itu sangat dilarang dalam Islam. Dalam Al-Qur'an, masalah zina disebutkan berbarengan dengan dosa-dosa

29 Syaikh Imam Al-Qurtubi, Tafsir Al Qurtubi, Penerjemah Ahmad Khotib, (Surah AlHijr, Annaml, Al Israa dan Al-Kahfi), hal. 628 
besar seperti kekafiran, pembunuhan, dan pencurian.

Dan jika dilihat dari pakaian si wanita pada foto prewedding pada pose ini menunjukkan lebih seksi ketimbang pose cium kening. Karena pakaian yang dikenakan si wanita ini cukup pendek dan bagian lengan juga terlihat transparan, sehingga itu menampakkan warna kulit dari si wanita. Ahli ilmu menafsirkan, "Perempuan yang berpakaian tapi telanjang," sebagai perempuang yang mengenakan pakaian sempit, atau pakaian tipis yang tidak menutupi bagian tubuh di bawahnya, atau pakaian pendek. Syaikhul Islam menjelaskan bahwa pakaian kaum perempuan di dalam rumah pasa masa Nabi SAW adalah antara mata kaki dan telapak tangan, bagian tubuh keduanya tertutupi meski mereka berada di dalam rumah. Sedangkan jika mereka keluar menuju pasar, sudah diketahui bersama bahwa sebelumnya kaum perempuan masa sahabat mengenakan pakaian panjang yang menjulur ke tanah, lalu nabi SAW memberikan keringanan bahwa mereka boleh menjulurkan (jilbab) hingga ke lengan, tidak lebih dari itu. ${ }^{30}$

Demikianlah, banyak sekali pada zaman sekarang pakaian yang tidak menutupi aurat wanita. Bisa jadi karena pakaian itu terlalu sempit sehingga auratnya menonjol atau pakaian tersebut pendek atau terbuka sehingga tersingkaplah sebagian dari auratnya. Ada juga yang tembus pandang sehingga wanita yang mengenakannya bisa dikatakan berbusana tapi hakikatnya telanjang. Alasannya, pakaian transparan tidak hanya mempertontonkan auratnya, tapi juga lebih

30 Syaikh Muhammad Bin Shalih AlUtsaimin, Ensiklopedia Halam Dan Haram Dalam Islam, (Solo: Zam Zam Mata Air ilmu, 2013), hal. 539 menimbulkan ransangan dibanding seandainya aurat ini benar-benar terbuka. ${ }^{31}$

Perempuan seperti ini diancam oleh Rasulullah SAW dengan ancaman yang keras, yaitu tidak masuk surga dan tidak dapat menghirup aromanya. Hendaklah setiap muslimah itu mengkoreksi dirinya masing-masing dan melihat apa yang dikenakan sebelum ancaman itu mengenai dirinya. kemudian yang termasuk dalam kategori pakaian yang serupa dan itu dilarang adalah semua yang mempertontonkan aurat, yang menyerupai wanita-wanita kafir dan mengikuti mode perkembangan zaman. ${ }^{32}$ Seperti layaknya dalam konsep pakaian dalam foto prewedding di atas juga tergolong haram, karena mengandung unsur ikhtilat, khalwat \& kasyaful aurat.

\section{Pose merangkul}

Pada foto prewedding di atas terlihat calon pengantin yang sedang beradegan mesra layaknya pasangan suami dan isteri. $\mathrm{Si}$ laki-laki ada yang menempelkan badannya dari belakang sembari memegang lengan si wanita, saling merangkul dan dengan jarak antara kedua muka begitu dekat.

Sama dengan foto prewedding sebelumnya, foto prewedding pose ini juga mengandung unsur khalwat dan ikbtilat yang merupakan perbuatan mendekati zina seperti apa yang dimaksud pada Q.S AlIsraa (17) ayat 32 sebelumnya. Tetapi jika dibandingkan dengan foto prewedding yang pertama dan kedua, nilai plus seorang wanita pada foto prewedding pose ini adalah si wanita mengenakan pakaian yang menutupi aurat dan berkerudung, sebagaimana kriteria pakaian yang Syar'i menurut Abdul Wahab sekurangkurangnya ada lima kriteria pakaian

\footnotetext{
31 Muhammad Basyir ath-Thahlawi, Ensikopedi Larangan dalam Syariat Islam, (Bogor: Media Tarbiyah, 2007), hal. 164

32 Ibid, hal. 165
} 
muslimah yang sesuai dengan ajaran AlQur'an dan Hadist, yaitu: ${ }^{33}$

1. Busana muslimah harus menutupi seluruh tubuhnya dari pandangan lelaki yang bukan mahramnya.

2. Hendaknya busana yang dipakai wanita muslimah menutup apa yang ada dibaliknya (tidak tipis menerawang).

3. Busana tidak ketat membentuk bagian-bagian tubuh.

4. Busana muslimah tidak menyerupai pakaian laki-laki.

5. Kemuduian warna busana yang dipakai tidak menarik perhatian.

Wanita pada pada foto prewedding pose ini telah memenuhi standar pakaian yang baik menurut Syariat Islam di atas. Tetapi sangat disayangkan, walau si wanita telah mengenakan pakaian yang sopan, namun unsur ikbtilat dan khalwat yang merupakan perilaku mendekati zina sebagai mana tafsir Q.S Al-Israa (17) ayat 32 tetap tidak bisa dihindarkan. Akhirnya pada foto prewedding pose ini walaupun si wanita telah berpakaian syar'i, tetapi tergolong foto prewedding yang haram karena mengandung unsur ikbtilat dan khalwat.

Wanita muslimah yang baik itu ialah yang tidak mau berduaan dengan laki-laki dan akan menghindarinya menurut kesanggupannya. Tidak mencari-cari jalan untuk memaksa tetap berduaan dengan laki-laki dan juga tidak mendorong orang lain melakukannya. Begitu juga sebaliknya seorang laki-laki tidak boleh berduaan dengan dengan perempuan lain. Bahkan seandainya itu adalah ipar, keponakan, pembantu, perawat, dokter dan

33 Tantri Puspita Yazid dan Ridwan, Proses Persepsi Diri Mahasiswi Dalam Berbusana Muslimah, Jurnal Pemikiran Islam, Edisi Desember 2017 Vol. 41 No. 2, hal. 199. sebagainya. Betapa banyak kehormatan terkoyak akibat pertemuan terlarang ini. ${ }^{34}$

\section{Pose berjarak}

Pada pose ini terlihat kedua pasangan calon pengantin berpose dengan berjarak, hal ini seharusnya menjadi penerapan yang wajib dalam memilih kategori pose yang ada pada Mandhan Photogrpahy, namun sayangnya pada pose ini hanya sedikit yang tertarik untuk melakukannya, karena pada pose ini terlihat mengedepankan syar'i dengan tidak bersentuhan secara fisik dan menggunakan pakaian yang menutupi aurat. Oleh karena itu hal ini menjadi polemik bahwa pergaulan bebas yang mulai terlihat santai di muka umum bukanlah suatu hal yang tabu. Dampak ini bisa dirasakan oleh orang-orang di sekitar sektor kehidupan masyarakat tentunya akan buruk terhadap remaja, pendidikan, kesehatan, keagamaan, dan terhadap kehidupan keluarga. Sebab pergaulan bebas dan dampak negatifnya ditinjau dari pendidikan Islam adalah tata cara pergaulan antar manusia dengan sesama manusia terutama dengan lawan jenisnya yang mengarah pada pelaksanaan hubungan seks di luar nikah yang mempunyai konsekuensi destruksif dan berprilaku menyimpang yang mengarah pada pergaulan bebas yang bertentangan dengan nilai-nilai yang terkandung dalam pendidikan Islam. Pergaulan bebas dalam Islam tentunya adalah hal yang dilarang. Hal ini karena memiliki dampak yang sangat besar terhadap diri sendiri dan suatu masyarakat. Tentu saja Allah tidak akan melarang sesuatu yang tidak memiliki dampak terhadap manusia. Apalagi jika dampak tersebut buruk atau menyesatkan, tentu sudah pasti diharamkan dan sangat dilarang. Bahkan melakukannya berarti termasuk telah melakukan perbuatan keji

34 Muhammad Basyir ath-Thahlawi, Ensikopedi Larangan dalam Syariat Islam, (Bogor: Media Tarbiyah, 2007), hal. 170. 
karena sudah diberi akal namun tidak digunakan untuk memahaminya. ${ }^{35}$

Setiap manusia, baik laki-laki maupun perempuan memiliki kewajiban untuk menutupi aurat dan dilarang memperlihatkannya kepada orang lain selain dari yang muhrim. Bahkan ada batasan-batasan yang harus dijaga, mengingat bahwa manusia adalah mahluk yang bisa mengundang kesalahan dan khilaf. Untuk itu, menghindari pergaulan bebas maka mulailah dari menjaga aurat kita masing-masing. Hal ini dikarenakan dari matalah kemaksiatan dan segala hawa nafsu bisa bermula. Untuk itu, menjaga pandangan adalah hal yang harus dilakukan. Menjaga agar tidak terjadi pergaulan bebas bisa dilakukan dari menjaga pandangan kita sendiri agar tidak melihat hal-hal yang diharamkan. Antara muhrim dan non muhrim atau lawan jenis hendaknya kitapun menjaga pergaulan. Dengan lawan jenis sekiranya tidak terlalu mengumbar perasaan, apalagi sampai menimbulkan hal yang berpotensi menimbulkan fitnah. Selain itu dalam pergaulan hendaknya ada batasan hijab bukan berarti harus hijab secara fisik namun hijab secara jarak dan pembicaraan. Hendaklah pembicaraan tidak membicarakan hal-hal yang berbau seksual atau sensual, agar kejernihan pikiran tetap terjaga. $^{36}$

Hal yang lebih penting dari itu semua adalah menjaga nilai-nilai Islam dalam pergaulan. Jangan sampai pergaulan kita rusak karena tidak ada nilai-nilai islam didalamnya. Untuk itu hal-hal dalam rukun Iman, rukun Islam, Iman dalam Islam, hubungan akhlak dengan Iman, Islam dan

35 Darnoto dan Hesti Triyana Dewi, Pergaulan Bebas Remaja Di Era Milenial Menurut Perspektif Pendidikan Agama Islam, Jurnal Tarbawi Vol. 17. No. 1. Januari - Juni 2020, hal. 59.

36 Ricky Firmansyah, Abdullah Zaky Al Lutfi dan Muhamad Aziz Mulyana, Mengatasi Pergaulan Bebas Di Masyarakat Ilmiah, Journal of Teacher Professional, Vol 1, No, 2 Agustus 2020, hal. 69.
Ihsan, dan Hubungan akhlak dengan Iman harus tetap dipegang teguh dalam setiap pergaulan dan kehidupan sosial kita. ${ }^{37}$ Alhasil penulis menarik analisis bahwa untuk menjaga kestabilan emosional dan psikis seorang manusia agar terhindar dari pikiran-pikiran yang mengarah kepada perilaku yang dilarang sesuai dalam AlQur'an dan Hadist, ada baiknya dalam hal ini semua elemen berperan penting dalam menunjang pembentukan pribadi manusia yang baik dan berakhlakul karimah yaitu dimulai sejak dini. Tentu disini peran yang paling utama adalah orang tua karena orang tua merupakan orang yang paling dekat dan tentu menjadi contoh bagi orang yang berada dilingkungan rumah. Kemudian sekolah atau lingkungan pendidikan merupakan faktor penting dalam membentuk karakter manusia demi menciptakan generasi yang baik untuk dimasa mendatang, dan juga lingkungan masyarakat tentunya.

Oleh sebab itu untuk menghindari persepsi ketika sudah mulai dewasa kemudian menikah, dan ingin mengikuti trend foto prewedding, merekapun menikmati sesi foto dengan ikhtilat, khalwat dan kasyaful aurat dimana itu dianggap hal yang biasa pada masa kini. Seandainya saja foto yang dipamerkan bukanlah foto prewedding yang saling bermesraan dan mengumbar aurat, yaitu foto preweddingi yang difoto secara terpisah dan menutup auratpun tetap memberikan informasi yang jelas terkait foto tersebut bahwa merekalah calon suami dan isteri yang akan segera mengadakan hajatan, tanpa harus dalam kondisi bermesraan dan mengumbar aurat.

Menurut hemat penulis bahwa hal itu jauh lebih baik, aman dan Syar'i dibanding harus saling bersentuhan. Pada saat pendemi virus Covid-19 ini saja melakukan apapun harus mematuhi prokes $5 \mathrm{M}$, salah satunya adalah menjaga jarak

${ }^{37}$ Ibid, hal. 70 
satu meter sampai dua meter, itu dilakukan untuk menghindarkan diri dari kontak sentuh yang mengakibatkan tertularnya virus Covid-19 dan tentu mengakibatkan kerugian bagi keduanya bahkan lebih. Dengan adanya jaga jarak tersebut alhasil membuat sesama kita tetap aman dan terhindar dari terpaparnya virus Covid-19.

Begitu pula jarak pemisah dalam beradegan dan busana yang Syar'i seharusnya wajib di terapkan demi menghindarkan diri masing-masing dari kemudharatan yang di larang Syariat Islam. Dan bila hal itu telah di terapkan, insyaAllah akan memberikan efek positif bagi calon pengantin yang menginginkan adanya sesi pemotretan prewedding. Terlebih juga berdampak positif bagi para calon pengantin lain yang juga ingin melaksanakan sesi pemotretanp prewedding. Hingga di harapkan kebiasaan foto prewedding yang umumnya mengandung unsur ikbtilat, khalwat, dan kasyful aurat, berubah menjadi menjaga jarak dan berbusana Syar'i.

Sebenarnya hal ini merupakan koreksi bagi Mandhan Photography, bahkan juga bagi seluruh fotografer prewedding untuk tidak membiarkan para pelanggannya memilih beradegan mesra dan berpakaian terbuka aurat pada sesi pemotretan dan tetap mengedepankan sesi foto pose berjarak, karena bagaimanapun juga ia pun terlibat dalam pemotretan tersebut dan ikut turut mendapatkan dosa disebabkan sikap rela terhadap kemaksiatan yang ada di hadapannya setiap kali pemotretan.

\section{HUKUM ISLAM DAN AKTUALISASI PADA FOTO PREWEDDING}

Berdasarkan temuan penelitian ini, diketahui bahwa tiga dari empat pose dalam berfoto prewedding, tidak sesuai dengan Syariat Islam. Hanya satu yang sesuai yaitu, pose foto berjarak. Maka, perlu diketahui lebih mendalam tentang hukum Islam dan relevansinya dalam pelaksanaan foto prewedding.

Majelis Ulama Indonesia (MUI) Sumatera Utara mengeluarkan fatwa bahwa foto pre wedding adalah haram. Menurut Prof. Dr. Abdullah Syah, MA mengatakan bahwa foto prewedding yang dimaksud adalah foto mesra calon suami dan calon istri yang dilakukan sebelum akad nikah. Foto pre wedding diharamkan karena saat berfoto itu mereka belum memiliki ikatan apa-apa. Itu tidak dibenarkan dalam hukum Islam. Allah SWT dalam beberapa ayat telah menerangkan bahaya zina dan menganggapnya sebagai perbuatan sangat buruk. $^{38}$

Wakil Sekretaris Komisi Fatwa MUI Asrorun Ni'am Sholeh juga perpendapat bahwa pengambilan foto untuk mengenalkan siapa yang akan menikah itu tidak apa-apa selama tidak melanggar ketentuan Syari'at. Kemudian ia juga mengatakan pengambilan foto prewedding tidak dilarang. Ia berpendapat foto prewedding itu bisa digunakan diundangan pernikahan atau ketika acara pernikahan, kecuali foto yang diambil dengan berciuman atau melanggar Syari'at itu jelas tidak boleh. ${ }^{39}$

Seperti diberitakan, Forum Musyawarah Pondok Pesantren Putri (FMP3), dari hasil bahtsul masail 2011 lalu, menetapkan hukum haram terhadap pemotretan prewedding. Hal ini berlaku bagi pasangan calon mempelai yang akan menikah dan fotografer yang mengambil gambarnya, tentu ini merujuk pada Q.S AlIsraa ayat 32 yang mana Dalam ayat tersebut Allah SWT melarang hamba-Nya untuk berbuat zina dan mendekatinya.

${ }^{38}$ https://www.muisumut.com/blog/2019/03 /31/foto-sebelum-pernikahan-pra-wedding-photo/. Diakses pada tgl 25 Agustus 2021 pada jam 13.10 WIB.

39 https://nasional.kompas.com/read/2010 /01/17/12181070/MUI..Foto..quot.Pre.Wedding. quot..Masih.Boleh. Diakses pada tgl 25 Agustus 2021 pada jam 14.00 WIB. 
Begitu pula tidak boleh menerjang hal-hal yang mendekati dan mendorong untuk berbuat zina. Demikian kata Ibnu Katsir dalam tafsirnya. Jadi, dalil tersebut secara umum menunjukkan terlarangnya zina dan hal-hal yang mendekati zina, termasuk di sini adalah berdua-duaan saat foto prewedding. ${ }^{40}$

Beberapa kesalahan saat melaksanakan foto prewedding yaitu ikbtilat (percampuran antara laki-laki dan perempuan), khalwat (berduaan antara pasangan yang belum halal), membuka aurat, bersentuhan dengan lawan jenis yang haram dan tabarruj. Pada pada akhirnya pelaksaaan foto prewedding sebelum akad nikah bukaanya tidak boleh sama sekali, tetapi tetap harus memperhatikan batasan-batasan secara Syariat, kalau hanya sekedar foto biasabiasa aja tidaklah masalah.

Berdasarkan tinjauan hukum Islam di atas maka penulis memberikan beberapa contoh prewedding yang sekiranya tidak melanggar unsur ikbtilat, khalwat dan kasyaful aurat. bagi mereka yang akan melaksanakan pemotretan. Di antaranya:

Foto Prewedding (solusi) No. 1

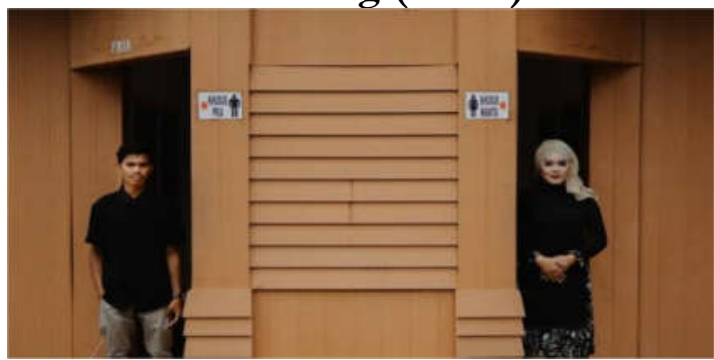

Sumber:

https:/ / www.instagram.com/p/B2RxjhKpnIN/ ?utm source $=i g$ web copy link. ${ }^{41}$

Terlihat pose pada foto prewedding di atas sepasang calon pengantin yang sedang

40 Ridwan, Agus Muhammad Dahlan, PESANTREN LIRBOYO (Sejarah, Peristiwa, Fenomena dan Legenda), Kediri: BKP P2L), hal. 233.

https://www.instagram.com/p/B2RxjhKpnlN/?ut m_source=ig_web_copy_link. Diakses pada tgl 25 Agustus 2021 pada jam 13.10 WIB. mengadakan sesi foto prewedding yang mengambil tema didepan pintu WC umum. Dari foto tersebut menjelaskan bahwa, jangankan untuk menyentuh, memandang saja ia tak mampu karena terhalangan oleh pembatas WC umum yang cukup jauh, ternyata mampu menghindarkan keduanya dari perilaku ikbtilat dan khalwat. Ditambah si wanita yang mengenakan kain kerudung dan pakaian yang menutup aurat dan longgar, semakin menambah keindahan foto prewedding tersebut.

\section{Foto Prewedding (solusi) No. 2}

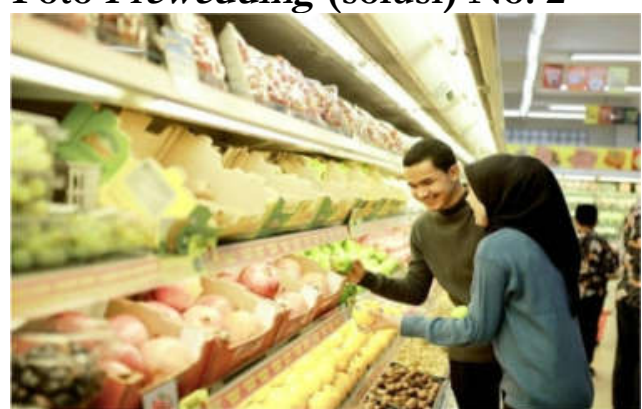

Sumber:

bttps:/ / www.instagram.com/p/B1 a48k2JkYs/ ?utm source $=$ ig web copy link. ${ }^{4}$

Pose sepasang calon pengantin di atas terlihat sedang melakukan sesi foto prewedding di pusat perbelanjaaan, tampak keduanya dalam posisi yang tidak bersentuhan, dimana si pria sibuk memilih buah, begitu juga si wanita. Tidak ada kontak fisik diantara keduanya dan tidak ada posisi berdua-duaan, karena di belakangnya terlihat lalu lalang pengunjung, dan pakaiannya juga termasuk pakaian yang sesuai ajaran Islam.

\section{Foto Prewedding (solusi) No. 3}

42

https://www.instagram.com/p/B1z48k2JkYs/?ut m_source $=$ ig_web_copy_link. Diakses pada tgl 25 Agustus 2021 pada jam 13.10 WIB. 


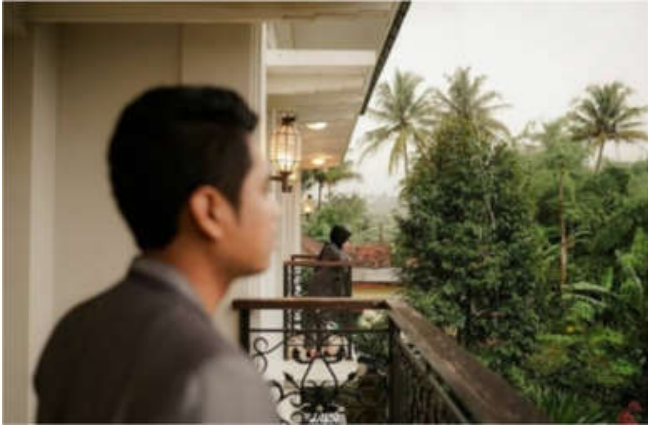

Sumber:

bttps:/ / www.instagram.com/p/CI2dxlfFtNG/ ?utm source $=$ ig web copy link. ${ }^{43}$

Pada foto prewedding ini terlihat sepasang calon pengantin yang sedang berpose saling berdiri di depan teras rumah. Keduanya sama-sama menghaadap kearah yg berbeda, dan kelihatannya jarak antara satu rumah kerumah berikutnya cukup jauh, jika dilihat sekilas seperti bukan foto prewedding dan tidak saling mengenali diantara keduanya. Kemudian tidak ada sentuh fisik sedikitpun dan menggunakan pakaian yang syar'i, tentu terbebas dari khalwat dan ikbtilat.

Itulah beberapa contoh solusi bagaimana seharusnya adegan dan busana dalam foto prewedding menurut Syari'at Islam. Tentunya dengan saling menjaga jarak dan terlepas dari membuka aurat seperti halnya beberpa contoh foto di atas, hal tersebut akan terlihat jauh lebih indah dan enak dipandang. Pada akhirnya penulis berpendapat bahwa hukum dari foto prewedding adalah boleh-boleh saja, namun bisa menjadi haram bila ada setitik terkandung unsur dari perilaku ikhtilat, khalwat dan membuka aurat seperti contoh foto prewedding karya Mandhan Photography.

\section{KESIMPULAN}

Proses pelaksanaan foto prewedding yang dilakukan oleh Mandhan Photography dilaksanakan sebelum akad pernikahan atau belum sah menjadi pasangan suami dan isteri. Dari analisis terhadap karya foto Mandhan Photography diketahui ada empat pose yakni, pose cium, pose memegang, pose merangkul dan pose berjarak. Pose-pose tersebut termasuk lokasi foto ditentukan oleh pelanggan. Berdasarkan analisis dari perspektif hukum Islam, maka diketahui bahwa ada tiga pose yang tidak sesuai yaitu, pose cium, pose memegang dan pose rangkul, kemudian satu pose yang sesuai dengan aturan hukum Islam yaitu pose berjarak. Maka dari itu proses pelaksanaan foto prewedding itu boleh dilakukan tetapi harus sesuai dengan aturan hukum Islam dilihat dari kesesuaian berpakaian dan penerapan pose pada saat sesi foto prewedding berlangsung. []
https://www.instagram.com/p/CI2dxlfFtNG/?ut m_source $=$ ig_web_copy_link, Diakses pada tgl 25 Agustus 2021 pada jam 13.10 WIB. 


\section{DAFTAR PUSTAKA}

Asnawi, Mohammad, Nikah dalam Perbincangan dan Perbedaan, (Jogja: Darussalam, 2004).

Darnoto dan Hesti Triyana Dewi, Pergaulan Bebas Remaja Di Era Milenial Menurut Perspektif Pendidikan Agama Islam, Jurnal Tarbawi Vol. 17. No. 1. Januari - Juni 2020.

Djakfar, Muhammad, Agama Etika, dan Ekonomi (Malang: UIN Press, 2007).

Ensiklopedi Nasional Indonesia, Jakarta: PT. Delta Pamungkas, 1997, Cet. Ke-3.

Fatoni, Abdurrahmat, Metodologi PenelitianTeknik Penyusunan Skripsi, (Jakarta: Rineka Cipta, 2006).

Firmansyah , Ricky, Abdullah Zaky Al Lutfi dan Muhamad Aziz Mulyana, Mengatasi Pergaulan Bebas Di Masyarakat Ilmiah, Journal of Teacher Professional, Vol 1, No, 2 Agustus 2020.

Hasil Wawancara bersama Mandhan Photogrpahy, fotografer prewedding Desa Pengudang, 15 Juni 2021.

Hasil wawancara dengan Mandhan Photography (fotografer prewedding), pada tanggal 13 Agustus 2021 di Desa Pengudang, Kecamatan Teluk Sebong, Kabupaten Bintan.

https://nasional.kompas.com/read/2010/ 01/17/12181070/MUI..Foto..quot.

Pre.Wedding.quot..Masih.Boleh. Diakses pada tgl 25 Agustus 2021 pada jam 14.00 WIB.

https://www.instagram.com/p/B1z48k2J $\mathrm{kYs} /$ ?utm source $=\mathrm{ig}$ web copy lin k. Diakses pada tgl 25 Agustus 2021 pada jam 13.10 WIB.

https://www.instagram.com/p/B2RxjhK $\mathrm{pnlN} /$ ?utm source=ig web copy li nk. Diakses pada tgl 25 Agustus 2021 pada jam 13.10 WIB.

https://www.instagram.com/p/CI2dxlfFt $\mathrm{NG} /$ ?utm source $=$ ig web copy lin k, Diakses pada tgl 25 Agustus 2021 pada jam 13.10 WIB. https://www.kemejingnet.com/2016/03/ arti-dan-pengertian-foto-prewedding.html

https://www.muisumut.com/blog/2019/ 03/31/foto-sebelum-pernikahanpra-wedding-photo/. Diakses pada tgl 25 Agustus 2021 pada jam 13.10 WIB.

Imam Ahmad bin Muhammad bin Hanbal, Musnad Imam Ahmad, Jilid 1, (Jakarta: Pustaka Azzam, 2009).

Kasih, Adindha Putri Arifianing, "Pandangan Masyarakat Terbadap Foto Prewedding Dalam Undangan Pernikahan Perspektif Hukum Islam", SKRIPSI IAIN Purwokerto 2019.

Kasiram, Moh., Metodologi Penelitian Kuantitatif-Kualitatif, (Malang: UMP, 2008).

Keputusan MUI se-Kalimantan Nomor 05/Fatwa/MUI-

Kalimantan/XII/2014, tentang Hukum Pembuatan Foto Prewedding dan Mencetaknya dalam Undangan.

Poerwandari, Kristi, Pendekatan Kwalitatif dalam penelitian Psikologi, Jakarta: Lembaga Pengembangan Sarana Pengukuran dan Pendidikan Psikologi, LPSP3UI ,1983).

Qardawi, Yusuf, Halal dan Haram, Tjr. Abu Sa ${ }^{e e i d ~ \& ~ A n n u r ~ R a f i q ~ S h a l e h ~}$ Tamhid, Jakarta: Robbani Press, 2002.

Qardhawi, Yusuf Al-, "Figh Muqasid Syariab” Terjemahan: Arif Munandar Riswanto, (Jakarta Timur: Pustaka Al-Kautsar, 2007).

Qardhawi, Yusuf Al-, Fatwa-Fatwa Mutakhir, tjr: H.M.H, Al-Hamid AlHusaini, Bandung: yayasan AlHamid, 2000, cet: 4.

Qurtubi, Syaikh Imam Al-, Tafsir $A l$ Qurtubi, Penerjemah Ahmad Khotib, (Surah Al-Hijr, Annaml, Al Israa dan Al-Kahfi).

Ridwan, Agus Muhammad Dahlan, PESANTREN LIRBOYO (Sejarah, 
Peristiwa, Fenomena dan Legenda), Kediri: BKP P2L), hal. 233.

Rosita, Kusnulia dan Yeniar Indriana. "Pengalaman Subjektif Istri yang Menikah dengan Proses Taaruf", (Jakarta:Empati, 2014).

Saebani, Beni Ahmad, Perkawinan Dalam Hukum Islam Dan Undang-Undang (Bandung: CV. Pustaka Setia, 2007).

Sahih Muslim, Kitab Pakaian dan Perbiasan, Bab: Wanita Berpakaian Tapi Telanjang, Nomor. 3971. Dibagikan Via Aplikasi Android Hadits alBukhari.

Sebagai isyarat kepada hadis Aisyah, "Manusia yang akan disiksa sangat pedih di hari kiamat adalah yang menandingi ciptaan Allah."HR. Al-Bukhari Kitab Al-Libas (5954)., dan Muslim, Kitab Al-Libas wa Az-Zinah (2107).

Soerjono, Pengantar Penelitian Hukum, (Jakarta : UI Press, 1986).

Syaikh Imam Al-Qurtubi, Tafsir Al Qurtubi, Penerjemah Ahmad Khotib, (Surah Al-Hijr, Annaml, Al Israa dan AlKahfi), (Pustaka Azzam: Jakarta Selatan, 2008).

Thabari, Abu Ja'far Muhammad bin Jarir Ath-, Tafsir Ath-Thabari, Penerjemah Abdul Somad, Yusuf Hamdani, (Jakarta Selatan: Pustaka Azzam, 2008).

Thahlawi, Muhammad Basyir ath-, Ensikopedi Larangan dalam Syariat Islam, (Bogor: Media Tarbiyah, 2007).

Thahlawi, Muhammad Basyir athThahlawi, Ensikopedi Larangan dalam Syariat Islam, (Bogor: Media Tarbiyah, 2007).

Utsaimin, Syaikh Muhammad Bin Shalih Al-, Ensiklopedia Halam Dan Haram Dalam Islam, (Solo: Zam Zam Mata Air ilmu, 2013).

www.kbbi.kemendikbud.go.id/berjarak, diakses pada 3 November 2021, pada jam 20.00 WIB. www.kbbi.kemendikbud.go.id/genggam, diakses pada 3 November 2021, pada jam 20.00 WIB.

www.kbbi.kemendikbud.go.id/mengecup, diakses pada 3 November 2021, pada jam 20.00 WIB.

www.kbbi.kemendikbud.go.id/merangkul, diakses pada 3 November 2021, pada jam 20.00 WIB.

Yazid, Tantri Puspita, dan Ridwan, Proses Persepsi Diri Mabasiswi Dalam Berbusana Muslimah, Jurnal Pemikiran Islam, Edisi Desember 2017 Vol. 41 No. 2. 